\title{
Determination of minimum inhibitory concentrations of lactic acid bacteria and other antagonist microorganisms
}

\author{
Svetlana Noskova $^{1, *}$, Stanislav Sukhikh ${ }^{1,2}$, Olga Babich $^{1,2}$, and Olga Bulgakova ${ }^{2}$ \\ ${ }^{1}$ Immanuel Kant Baltic Federal University, 14 A. Nevsky St., 236016 Kaliningrad, Russia \\ ${ }^{2}$ Kemerovo State University, 6 Krasnaya St., 650000 Kemerovo, Russia
}

\begin{abstract}
Minimum inhibitory concentrations of lactic acid bacteria and other antagonist microorganisms isolated from natural sources of Kaliningrad region (soil, water bodies, plant objects) were determined. It was shown that the minimum inhibitory concentration of Pediococcus pentosaceus metabolites against Escherichia coli is $1.5 \cdot 107 \mathrm{CFU} / \mathrm{ml}$; Pseudomonas chlororaphis metabolites have no inhibitory effect against the test strain of Escherichia coli under study. It was found that Pediococcus damnosus metabolites adversely affect the growth of Escherichia coli, but at a concentration of $1.5 \cdot 107 \mathrm{CFU} / \mathrm{ml}$ after $6-24$ hours of cultivation. For metabolites isolated by Lactobacillus casei, the characteristic minimum inhibitory concentration with respect to the studied Escherichia coli strain is $1.5-107 \mathrm{CFU} / \mathrm{ml}$, and for metabolites isolated by Lactobacillus fermentum, the minimum inhibitory concentration with respect to the studied Escherichia coli strain is $1.5 \cdot 105 \mathrm{CFU} / \mathrm{ml}$. At a concentration of Bacteroides hypermegas (Megamonas hypermegale) metabolites equal to $1.5 \cdot 106 \mathrm{CFU} / \mathrm{ml}$, an optical density lower than that of the control is observed. The minimum concentration of Pseudomonas syringae metabolites inhibiting Escherichia coli culture growth is 1.5-107 $\mathrm{CFU} / \mathrm{ml}$. For the metabolites Acetobacter aceti and Psychrobacter urativorans, the concentration of $1.5 \cdot 107 \mathrm{CFU} / \mathrm{ml}$ is the lowest to inhibit the growth of Escherichia coli.
\end{abstract}

\section{Introduction}

Bacteriocins have many advantages for therapeutic use, including their small size, biocompatibility, biodegradability, and in most cases their non-immunogenic nature [1]. However, questions regarding stability, solubility of bacteriocins, large-scale production, and purification in quantities sufficient for general medical use arise. Solid-phase or liquidphase synthesis methods and recombinant in vivo biotechnology methods are commonly applied to produce medical peptides. However, due to the complex nature of bacteriocin peptides and the need for posttranslational modification, such synthesis methods are expensive and impossible in large-scale production [2]. An additional problem of chemical

\footnotetext{
* Corresponding author: elen.ulrich@mail.ru
} 
synthesis is the design of long and/or hyperhydrophobic peptides that can self-aggregate [3].

Bacteriocins administered orally are sensitive to enzymatic degradation and a decrease in gastrointestinal $\mathrm{pH}$. The pharmacokinetics of bacteriocins, namely, intestinal absorption, bioavailability, distribution, half-life, renal clearance and excretion, requires in-depth study to date. Bacteriocins are expected to have a lower effective half-life than their antibiotic counterparts [4], due to their sensitivity to proteases in vivo. However, studies on chemically synthesized antimicrobial peptides including d-amino acids show that these are less susceptible to proteolytic cleavage in GIT [5]. Parenteral administration may offer options for preventing proteolytic degradation of bacteriocins [6], especially in cases where systemic infections exist. Parenterally administered bacteriocins will contact proteases involved in hemostasis and fibrinolysis in the bloodstream [7], which may reduce their activity. A solution to this problem is possible by removing protease recognition signs.

Compared to antibiotics, bacteriocins are less labile at high temperatures and under conditions of extreme $\mathrm{pH}$. The bacteriocins stability is related to their diverse structure and the level of posttranslational modifications (cyclization, disulfide bridges, and specific amino acids) required for activity [8]. Bioengineered variants of natural bacteriocins have demonstrated increased efficacy in studies that describe recombinant nisin $\mathrm{A}$ and $\mathrm{Z}$ compounds with modulated pharmacokinetic properties [9]. Regarding biocompatibility, class II bacteriocins, nisin and other lantipeptides proved to be non-cytotoxic against various eukaryotic cell lines at doses 100 times higher than the antibacterial drugs concentration [10]. Further study is needed to determine means of improving the stability and efficacy of bacteriocins for medical use. In addition, studies examining the exact mechanisms of resistance to bacteriocins will accelerate their use in clinical settings individually or as combination antimicrobials [11].

As the incidence of antibiotic-resistant infections increases worldwide due to diseases connected with pathogens of various origins, there is an urgent need to develop new antimicrobials. New antimicrobial agents should have different modes of action than currently used therapeutic agents in order to effectively combat resistance in pathogenic species. New substances that can be used alone or in combination with antibiotics, reducing the dose required for activity, are of primary importance. Bacteriocins demonstrate great potential because they exhibit multiple mechanisms of action, forming pores in membranes, inhibiting cell wall biosynthesis, and affecting cellular respiration. In addition, some bacteriocins, in particular nisin, have demonstrated sporicidal activity, activity against Gram-negative species, and activity against biofilms, confirming their potential clinical importance [12, 13].

Because of their ribosome-synthesized nature, bacteriocins are suitable for creating recombinant compounds that demonstrate increased efficacy for selecting bacterial strains at low level of cytotoxicity. Also, further studies are needed to determine suitable delivery mechanisms, since proteolytic cleavage in the intestinal tract may affect bacteriocin activity.

An important advantage of many bacteriocins is their low oral toxicity during treatment. Many bacteriocins produced in particular by lactic acid bacteria have been consumed in fermented foods for thousands of years. The lack of toxicity of Nisin and other lantibiotics has been demonstrated in several studies. It should be noted that cytolysin (lantibiotic) associated with Enterococcus spp. is a cytotoxin, but it is currently the only lantibiotic with this property [14].

Another advantage is the possibility of using probiotics as producers of bacteriocins. It has previously been shown that many intestinal bacteria require bacteriocin production to colonize the gut. For example, when an MccV producer and its nonproducing bacteriocin recombinant were injected together in mice, the nonproducing strain could not sustain the 
competition and was thus eliminated from the colon. Regarding probiotic intestinal microorganisms, bacteriocin production has long been considered a beneficial property, but the evidence confirming this theory has often been circumstantial and insufficient [15].

The protein nature of bacteriocins expands the possibilities for their production, which is impossible for classical antibiotics. Bacteriocins can be constructed by obtaining recombinant genes, involve the in vitro use of biosynthetic enzymes necessary for peptide production, and depend on partial or complete chemical synthesis of antimicrobial agent. In most cases, engineered peptides are important for expanding knowledge of bacteriocin activity. However, there is a growing number of recombinant peptides that demonstrate increased functionality, which makes them more attractive clinically.

For any antimicrobial drug being studied for clinical use, the potential emergence of resistant pathogens is a problem that should be solved. Bacteriocins have not been widely used in clinical settings, so an understanding of the potential threat of these antimicrobials has been revealed primarily through laboratory studies. Resistance can be developed by imitating the natural protective immunity of producer strains, enzymatic degradation of bacteriocin, cell membrane adaptation, and growth conditions. In addition, since bacterial membrane surface charge and variability are key factors in bacteriocin toxicity, changes in these factors contribute to bacterial resistance [16].

The clinical application of bacteriocins will depend on understanding their action mechanisms and developing strategies to prevent or reduce resistance in the future. The production of modified bacteriocins and the search for new strains-producers is an important step, but this study should be accompanied by the development of processes that will allow the production of sufficient amounts of antimicrobials without loss of functional activity. Nevertheless, given the huge number of different available compounds, their various structures, action mechanisms and production methods, the study of bacteriocins is one of the promising and practically significant directions in the field of microbiology [17].

The paper's goal was to determine the minimum inhibitory concentrations of lactic acid bacteria and other antagonist microorganisms isolated from natural sources of Kaliningrad region in relation to opportunistic and pathogenic microorganisms.

\section{Materials and Methods}

To determine the minimal inhibitory concentrations of lactic acid bacteria and other antagonist microorganisms isolated from natural sources of Kaliningrad region (soil, water bodies, plant objects) and being bacteriocins, primary and secondary metabolites were isolated by centrifugation [18]. In the first stage, the liquid nutrient medium was centrifuged at a rotor speed of $10,000 \mathrm{rpm}$ for $20 \mathrm{~min}$, the supernatant was separated and then filtered through $22 \mu \mathrm{m}$ filters (Millipore, USA) into sterile tubes.

The minimum inhibitory (suppressive) concentrations of LAB metabolites and other antagonist microorganisms against Escherichia coli were determined using the following procedure. The microorganisms were cultured for $24 \mathrm{~h}$ at $37{ }^{\circ} \mathrm{C}$. The culture liquid was then centrifuged at 7,000 rpm for $10 \mathrm{~min}$, after which the supernatant was removed.

The culture fluid turbidity was adjusted to a McFarland standard of 0.5 . The optical suspension density was adjusted spectrophotometrically at a wavelength of $625 \mathrm{~nm}$. Then, a series of successive 1:10 dilutions were prepared from the test solution to a certain concentration of matabolites $\left(10^{8}\right.$ to $\left.10^{5} \mathrm{CFU} / \mathrm{ml}\right)$.

A pure daily culture of microorganisms grown on dense nutrient media was used to create the inoculum. The optical density was measured for $24 \mathrm{~h}$. A mixture of pure nutrient medium and inoculum was used as a control. The minimum inhibitory concentration (MIC) was the lowest concentration at which the growth and development of the tested microorganism was observed [19]. 


\section{Results and Discussion}

The results of determining the minimum inhibitory concentrations of lactic acid bacteria and other antagonist microorganisms isolated from natural sources of Kaliningrad region (soil, water bodies, plant objects) are presented in Table 1.

Table 1. The results of determining the minimum inhibitory concentrations of lactic acid bacteria and other antagonist microorganisms isolated from natural sources of Kaliningrad region (soil, water bodies, plant objects) in relation to $E$. coli.

\begin{tabular}{|c|c|c|c|c|c|}
\hline \multirow{2}{*}{$\begin{array}{l}\text { Cultivation } \\
\text { duration, } h\end{array}$} & \multicolumn{5}{|c|}{ Concentrations of metabolites, CFU/ml } \\
\hline & $1.5 \cdot 10^{8}$ & $1.5 \cdot 10^{7}$ & $1.5 \cdot 10^{6}$ & $1.5 \cdot 10^{5}$ & control \\
\hline \multicolumn{6}{|c|}{ Lactobacillus casei } \\
\hline 0 & $\begin{array}{l}0.0324 \pm \\
\pm 0.0016\end{array}$ & $\begin{array}{l}0.0266 \pm \\
\pm 0.0013\end{array}$ & $\begin{array}{l}0.0184 \pm \\
\pm 0.0009\end{array}$ & $\begin{array}{l}0.0088 \pm \\
\pm 0.0004\end{array}$ & $\begin{array}{l}0.0416 \pm \\
\pm 0.0021\end{array}$ \\
\hline 2 & $\begin{array}{l}0.0305 \pm \\
\pm 0.0015\end{array}$ & $\begin{array}{l}0.0255 \pm \\
\pm 0.0013\end{array}$ & $\begin{array}{l}0.0181 \pm \\
\pm 0.0009\end{array}$ & $\begin{array}{l}0.0080 \pm \\
\pm 0.0004\end{array}$ & $\begin{array}{l}0.0448 \pm \\
\pm 0.0022\end{array}$ \\
\hline 4 & $\begin{array}{l}0.1026 \pm \\
\pm 0.0051\end{array}$ & $\begin{array}{l}0.1086 \pm \\
\pm 0.0054\end{array}$ & $\begin{array}{l}0.0667 \pm \\
\pm 0.0033\end{array}$ & $\begin{array}{l}0.0589 \pm \\
\pm 0.0029\end{array}$ & $\begin{array}{l}0.0689 \pm \\
\pm 0.0034\end{array}$ \\
\hline 6 & $\begin{array}{l}0.2461 \pm \\
\pm 0.0123\end{array}$ & $\begin{array}{l}0.2775 \pm \\
\pm 0.0139\end{array}$ & $\begin{array}{l}0.2497 \pm \\
\pm 0.0125\end{array}$ & $\begin{array}{l}0.2886 \pm \\
\pm 0.0144\end{array}$ & $\begin{array}{l}0.2305 \pm \\
\pm 0.0115\end{array}$ \\
\hline 24 & $\begin{array}{l}0.3399 \pm \\
\pm 0.0170\end{array}$ & $\begin{array}{l}0.3144 \pm \\
\pm 0.0157\end{array}$ & $\begin{array}{l}0.3172 \pm \\
\pm 0.0159\end{array}$ & $\begin{array}{l}0.3339 \pm \\
\pm 0.0170\end{array}$ & $\begin{array}{l}0.3108 \pm \\
\pm 0.0155\end{array}$ \\
\hline \multicolumn{6}{|c|}{ Lactobacillus fermentum } \\
\hline 0 & $\begin{array}{l}0.0742 \pm \\
\pm 0.0037\end{array}$ & $\begin{array}{l}0.0677 \pm \\
\pm 0.0034\end{array}$ & $\begin{array}{l}0.0578 \pm \\
\pm 0.0029\end{array}$ & $\begin{array}{l}0.0443 \pm \\
\pm 0.0022\end{array}$ & $\begin{array}{l}0.0721 \pm \\
\pm 0.0036\end{array}$ \\
\hline 2 & $\begin{array}{l}0.0725 \pm \\
\pm 0.0036\end{array}$ & $\begin{array}{l}0.0658 \pm \\
\pm 0.0033\end{array}$ & $\begin{array}{l}0.0507 \pm \\
\pm 0.0025\end{array}$ & $\begin{array}{l}0.0419 \pm \\
\pm 0.0021\end{array}$ & $\begin{array}{l}0.0755 \pm \\
\pm 0.0038\end{array}$ \\
\hline 4 & $\begin{array}{l}0.0893 \pm \\
\pm 0.0045\end{array}$ & $\begin{array}{l}0.1013 \pm \\
\pm 0.0051\end{array}$ & $\begin{array}{l}0.0977 \pm \\
\pm 0.0049\end{array}$ & $\begin{array}{l}0.0905 \pm \\
\pm 0.0045\end{array}$ & $\begin{array}{l}0.1329 \pm \\
\pm 0.0066\end{array}$ \\
\hline 6 & $\begin{array}{l}0.0948 \pm \\
\pm 0.0047\end{array}$ & $\begin{array}{l}0.1666 \pm \\
\pm 0.0083\end{array}$ & $\begin{array}{l}0.1974 \pm \\
\pm 0.0099\end{array}$ & $\begin{array}{l}0.1053 \pm \\
\pm 0.0053\end{array}$ & $\begin{array}{l}0.1843 \pm \\
\pm 0.0092\end{array}$ \\
\hline 24 & $\begin{array}{l}0.1275 \pm \\
\pm 0.0064\end{array}$ & $\begin{array}{l}0.0802 \pm \\
\pm 0.0040\end{array}$ & $\begin{array}{l}0.3012 \pm \\
\pm 0.0151\end{array}$ & $\begin{array}{l}0.3433 \pm \\
\pm 0.0172\end{array}$ & $\begin{array}{l}0.2525 \pm \\
\pm 0.0126\end{array}$ \\
\hline \multicolumn{6}{|c|}{ Bacteroides hypermegas (Megamonas hypermegale) } \\
\hline 0 & $\begin{array}{l}0.0993 \pm \\
\pm 0.0047\end{array}$ & $\begin{array}{l}0.0868 \pm \\
\pm 0.0043\end{array}$ & $\begin{array}{l}0.0755 \pm \\
\pm 0.0038\end{array}$ & $\begin{array}{l}0.0651 \pm \\
\pm 0.0033\end{array}$ & $\begin{array}{l}0.0921 \pm \\
\pm 0.0046\end{array}$ \\
\hline 2 & $\begin{array}{l}0.0304 \pm \\
\pm 0.0015\end{array}$ & $\begin{array}{c}00966 \pm \\
\pm 0.0048\end{array}$ & $\begin{array}{l}0.0741 \pm \\
\pm 0.0037\end{array}$ & $\begin{array}{l}0.0628 \pm \\
\pm 0.0031\end{array}$ & $\begin{array}{l}0.1156 \pm \\
\pm 0.0058\end{array}$ \\
\hline 4 & $\begin{array}{l}0.0360 \pm \\
\pm 0.0018\end{array}$ & $\begin{array}{l}0.1342 \pm \\
\pm 0.0067\end{array}$ & $\begin{array}{c}0.0946 \pm \\
\pm 0.047\end{array}$ & $\begin{array}{l}0.1315 \pm \\
\pm 0.0066\end{array}$ & $\begin{array}{l}0.1329 \pm \\
\pm 0.0066\end{array}$ \\
\hline 6 & $\begin{array}{l}0.0753 \pm \\
\pm 0.0038\end{array}$ & $\begin{array}{l}0.1763 \pm \\
\pm 0.0088\end{array}$ & $\begin{array}{l}0.1523 \pm \\
\pm 0.0076\end{array}$ & $\begin{array}{l}0.3383 \pm \\
\pm 0.0169\end{array}$ & $\begin{array}{l}0.1843 \pm \\
\pm 0.0092\end{array}$ \\
\hline 24 & $\begin{array}{l}0.0423 \pm \\
\pm 0.0021\end{array}$ & $\begin{array}{l}0.1042 \pm \\
\pm 0.0052\end{array}$ & $\begin{array}{l}0.1991 \pm \\
\pm 0.0099\end{array}$ & $\begin{array}{l}0.3619 \pm \\
\pm 0.0181\end{array}$ & $\begin{array}{c}0.1921 \pm \\
\pm 0.096\end{array}$ \\
\hline
\end{tabular}


Table 1. Continued

\begin{tabular}{|c|c|c|c|c|c|}
\hline \multicolumn{6}{|c|}{ Pseudomonas syringae } \\
\hline \multirow{2}{*}{0} & $0.0413 \pm$ & $0.0341 \pm$ & $0.0240 \pm$ & $0.0160 \pm$ & $0.0464 \pm$ \\
& \pm 0.0021 & \pm 0.0017 & \pm 0.0012 & \pm 0.0008 & \pm 0.0023 \\
\hline \multirow{2}{*}{2} & $0.0489 \pm$ & $0.0484 \pm$ & $0.0750 \pm$ & $0.0870 \pm$ & $0.1448 \pm$ \\
& \pm 0.0024 & \pm 0.0024 & \pm 0.0037 & \pm 0.0043 & \pm 0.0072 \\
\hline \multirow{2}{*}{4} & $0.0472 \pm$ & $0.0907 \pm$ & $0.0920 \pm$ & $0.0960 \pm$ & $0.6898 \pm$ \\
& \pm 0.0024 & \pm 0.0045 & \pm 0.0046 & \pm 0.0048 & \pm 0.0345 \\
\hline \multirow{2}{*}{6} & $0.1509 \pm$ & $0.1931 \pm$ & $0.2750 \pm$ & $0.2780 \pm$ & $0.2305 \pm$ \\
& \pm 0.0075 & \pm 0.0097 & \pm 0.0137 & \pm 0.0139 & \pm 0.0115 \\
\hline \multirow{2}{*}{24} & $0.1511 \pm$ & $0.3652 \pm$ & $0.4090 \pm$ & $0.4490 \pm$ & $0.3008 \pm$ \\
& \pm 0.0076 & \pm 0.0183 & \pm 0.0205 & \pm 0.0224 & \pm 0.0150 \\
\hline \multirow{2}{*}{0} & & & & \\
& & & & & \\
\hline \multirow{2}{*}{2} & $0.0456 \pm$ & $0.0489 \pm$ & $0.0596 \pm$ & $0.0603 \pm$ & $0.0665 \pm$ \\
& \pm 0.0023 & \pm 0.0024 & \pm 0.0030 & \pm 0.0030 & \pm 0.0033 \\
\hline \multirow{2}{*}{4} & $0.0539 \pm$ & $0.0632 \pm$ & $0.0771 \pm$ & $0.0905 \pm$ & $0.0886 \pm$ \\
& \pm 0.0027 & \pm 0.032 & \pm 0.0039 & \pm 0.0045 & \pm 0.0044 \\
\hline \multirow{2}{*}{6} & $0.0724 \pm$ & $0.0885 \pm$ & $0.0122 \pm$ & $0.1254 \pm$ & $0.1247 \pm$ \\
& \pm 0.0036 & \pm 0.0044 & \pm 0.0006 & \pm 0.0063 & \pm 0.0062 \\
\hline \multirow{2}{*}{24} & $0.1134 \pm$ & $0.1178 \pm$ & $0.1668 \pm$ & $0.1689 \pm$ & $0.1654 \pm$ \\
& \pm 0.0057 & \pm 0.0059 & \pm 0.0083 & \pm 0.0084 & \pm 0.0083 \\
\hline \multirow{2}{*}{$0.1168 \pm$} & $0.1235 \pm$ & $0.2350 \pm$ & $0.2400 \pm$ & $0.2356 \pm$ \\
& \pm 0.0058 & \pm 0.0062 & \pm 0.0117 & \pm 0.0120 & \pm 0.0118 \\
\hline
\end{tabular}

Analysis of the results presented in Table 1 shows that at concentrations of metabolites excreted by Pediococcus pentosaceus from $1.5 \cdot 10^{8}$ to $1.5 \cdot 10^{7} \mathrm{CFU} / \mathrm{mL}$, the growth and development of $E$. coli is significantly lower compared to controls. At a metabolite concentration of $1.5 \cdot 10^{6} \mathrm{CFU} / \mathrm{ml}$, the E. coli growth is lower than that of the control up to and including $6 \mathrm{~h}$ of cultivation, but at a cultivation duration of $24 \mathrm{~h}$, a pathogen concentration similar to the control is observed.

Thus, the minimum suppressive concentration of Pediococcus pentosaceus metabolites as related to E. coli is $1.5 \cdot 10^{7} \mathrm{CFU} / \mathrm{ml}$.

The growth of E. coli in the presence of Pseudomonas chlororaphis metabolites is comparable to the control during the day of cultivation. Thus, it can be concluded that the metabolites of Pseudomonas chlororaphis have no inhibitory effect against the test strain $E$. coli under study. The situation is different with Pediococcus damnosus. It was shown that Pediococcus damnosus metabolites adversely affect the growth of E. coli, but at a concentration of $1.5 \cdot 10^{7} \mathrm{CFU} / \mathrm{ml}$ after 6-24 hours of cultivation.

For primary and secondary metabolites isolated by Lactobacillus casei, the characteristic minimum inhibitory concentration with respect to the studied E. coli strain is $1.5-10^{7} \mathrm{CFU} / \mathrm{ml}$, and for metabolites isolated by Lactobacillus fermentum, the minimum inhibitory concentration with respect to the studied E. coli strain is $1.5 \cdot 10^{5} \mathrm{CFU} / \mathrm{ml}$.

At a concentration of Bacteroides hypermegas (Megamonas hypermegale) metabolites equal to $1.5 \cdot 10^{6} \mathrm{CFU} / \mathrm{ml}$, an optical density lower than that of the control is observed, which is a consequence of stunted growth of Escherichia coli. The minimum concentration of Pseudomonas syringae metabolites inhibiting E. coli culture growth is $1.5-10^{7} \mathrm{CFU} / \mathrm{ml}$. 
For the metabolites Acetobacter aceti and Psychrobacter urativorans, the concentration of $1.5 \cdot 10^{7} \mathrm{CFU} / \mathrm{ml}$ is the lowest to inhibit the growth of Escherichia coli.

\section{Conclusions}

Thus, minimum inhibitory concentrations of lactic acid bacteria and other antagonist microorganisms isolated from natural sources of Kaliningrad region (soil, water bodies, plant objects) were determined. It was shown that the minimum inhibitory concentration of Pediococcus pentosaceus metabolites against E. coli is $1.5 \cdot 10^{7} \mathrm{CFU} / \mathrm{ml}$; Pseudomonas chlororaphis metabolites have no inhibitory effect against the test strain of E. coli under study. It was found that Pediococcus damnosus metabolites adversely affect the growth of E. coli, but at a concentration of $1.5 \cdot 10^{7} \mathrm{CFU} / \mathrm{ml}$ after $6-24$ hours of cultivation. For metabolites isolated by Lactobacillus casei, the characteristic minimum inhibitory concentration with respect to the studied E. coli strain is $1.5-10^{7} \mathrm{CFU} / \mathrm{ml}$, and for metabolites isolated by Lactobacillus fermentum, the minimum inhibitory concentration with respect to the studied $E$. coli strain is $1.5 \cdot 10^{5} \mathrm{CFU} / \mathrm{ml}$. At a concentration of Bacteroides hypermegas (Megamonas hypermegale) metabolites equal to $1.5 \cdot 10^{6} \mathrm{CFU} / \mathrm{ml}$, an optical density lower than that of the control is observed. The minimum concentration of Pseudomonas syringae metabolites inhibiting E. coli culture growth is $1.5-107 \mathrm{CFU} / \mathrm{ml}$. For the metabolites Acetobacter aceti and Psychrobacter urativorans, the concentration of $1.5 \cdot 10^{7} \mathrm{CFU} / \mathrm{ml}$ is the lowest to inhibit the growth of Escherichia coli.

\section{Acknowledgements}

This work was financially supported by the Russian Foundation for Basic Research (scientific project No. №20-34-70004\19).

\section{References}

1. P. Baindara, S. Korpole, V. Grover, Appl. Microbiol. Biotechnol., 102 (2018)

2. M. P. Mokoena, Molecules, 22 (2017)

3. H. S. Abanoz, B. Kunduhoglu, Korean J. Food Sci. Anim. Resour., 38 (2018)

4. J. Ge, J. Kang, W. Ping, J. Microbiol. Biotechnol., 29 (2019)

5. P. Hols, L. Ledesma-García, P. Gabant, J. Mignolet Trends Microbiol., 27 (2019)

6. S. Chiorean, J.C. Vederas, M.J. van Belkum, Probiotics Antimicrob. Proteins., 10 (2018)

7. L. Dicks, L. Dreyer, C. Smith, A.D. van Staden, Front. Microbiol., 9 (2018)

8. Cameron, R. Zaheer, E.H. Adator, R. Barbieri, T. Reuter, T.A. McAllister, Toxins 11 (2019)

9. R. Kumariya, G. Kumari, Y.S. Raiput, N. Akhtar, S. Patel, Microb. Pathog., 128 (2019)

10. J. Zou, H. Jiang, H. Cheng, J. Fang, G. Huang, Int. J. Biol. Macromol., 117 (2018)

11. N. Jamaluddin, D.C. Stuckey, A.B. Ariff, F. Wong Crit Rev Food Sci Nutr, 58 (2018)

12. G. Rodrigues, G.G.O. Silva, D.F. Buccini, H.M. Duque, S.C. Dias, O.L. Franco, Front. Microbiol., 10 (2019)

13. H. Mathur, D. Field, M.C. Rea, P.D. Cotter, C. Hill, R.P. Ross, Front. Microbiol., 8 (2017) 
14. H. Mathur, D. Field, M.C. Rea, P.D. Cotter, C. Hill, R.P. Ross, NPJ Biofilms Microbiomes, 4 (2018)

15. B Lagha, B. Hass, M. Gottschalk, D. Grenier, Vet. Res., 48 (2017)

16. L. R. Lopetuso, M.E. Giorgio, A. Saviano, F. Scaldaferri, A. Gasbarrini, G. Cammarota, Int. J. Mol. Sci., 20, 183 (2019)

17. Tabata, T. Yamada, H. Ohtani, K. Ohkura, T. Tomoyasu, H. Nagamune, J. Oral Microbiol., 11 (2019)

18. S. V. Naveen, K. Kalaivani, Stem Cell Investig., 5 (2018)

19. P. Hols, L. Ledesma-García, P. Gabant, J. Mignolet, Trends Microbiol., 27 (2019) 